\section{Osteonecrosis Related to Once-Yearly Zoledronic Acid Treatment in an Osteoporotic Patient after Dental Implant}

Thais Gimenez Miniello ${ }^{1,2}$, Juliane Pirágine Araújo², Rodrigo Nascimento Lopes $^{1}$, Fabio Abreu Alves ${ }^{1,2}$
'Department of Stomatology, AC Camargo Cancer Center, São Paulo, SP, Brazil ${ }^{2}$ Department of Stomatology, School of Dentistry, USP - University of São Paulo, São Paulo, SP, Brazil.

Correspondence: Fábio Abreu Alves, Rua Prof. Antônio Prudente, 211, São Paulo, SP, Brasil. Tel: +55-11-2189-5129. e-mail: falves@accamargo.org.br

\begin{abstract}
This paper presents a case of osteonecrosis of the jaw related to zoledronic acid (5 mg) administered once yearly to treat osteoporosis. A 79-year-old woman who has been treated for osteoporosis for 5 years with 5 applications of zoledronic acid was referred for evaluation. The patient had been submitted to dental implant placement and there was no osseointegration. On clinical examination, suppuration and exposed bone on the alveolar ridge were observed. Radiographic examination revealed an osteolytic area and bone sequestration. Both clinical and radiological features were suggestive of osteonecrosis. The treatment consisted of surgery to remove the affected bone completely. The patient is asymptomatic at 9 months after surgery. Dentists and oral surgeons should be alert to the possibility of osteonecrosis related to the use of once-yearly injections of zoledronic acid for the treatment of postmenopausal osteoporosis.
\end{abstract}

Key Words: osteonecrosis of the jaw, bisphosphonate-associated osteonecrosis, once-yearly zoledronic acid, dental implants.

\section{Introduction}

Osteoporosis, which is defined as a systemic skeletal disorder, is characterized by intense osteoclastic activity and reduced formation of bone matrix. These alterations change the micro-architecture of bone, reducing its quality and making it more susceptible to fracture (1). Postmenopausal osteoporosis is often treated with bisphosphonates (BP). These drugs are incorporated in the mineral structure of the bone for long periods and decrease/inhibit bone turnover according to their potency, mechanism of action and the duration of therapy $(2,3)$. Adverse effects related to intravenous BP include acute systemic inflammatory reactions and osteonecrosis of the jaw (ONJ) (4).

The incidence of $\mathrm{ONJ}$ related to once-yearly $5 \mathrm{mg}$ zoledronic acid (ZA) application is not well defined in the literature. Grbic et al. (5) evaluated 3,248 patients treated with three injections of ZA (one a year), and only one patient developed spontaneous ONJ. In a recent review, Katz and Ordoveza (6) found 10 cases and added 2 new ones of ONJ related to annual administration of $5 \mathrm{mg}$ ZA to treat osteoporosis.

The aim of this report is to describe a case of ONJ related to once-yearly intravenous zoledronic acid, which was used to treat osteoporosis.

\section{Case Report}

A 79-year-old woman was referred to our Cancer Center to evaluate pain associated to exposed bone in the jaw. The patient has been taken 5 doses of ZA ( $5 \mathrm{mg}$, once yearly) to treat osteoporosis.

Two and three years before our consultation, the patient underwent two surgeries for placement of dental implants in the right side of the mandible. On both occasions, there was no osseointegration of the implants. On clinical examination, an area of exposed bone with pus drainage was observed on the region of attempted implant placement (Fig. 1A). Radiographs showed the presence of bone sequestrum on the alveolar ridge surrounded by an osteolytic area and bone sclerosis was observed on the right body of the mandible (Figs. $1 \mathrm{~B}$ and $1 \mathrm{C}$ ).

Based on clinical and imaging features, a diagnosis of ONJ related to BP was established. The treatment consisted of extensive surgery under general anesthesia to remove all necrotic bone. Furthermore, a peripheral ostectomy was performed to obtain bone bleeding. Sutures were placed to provide primary closure of the wound (Figs. 2A-C). The patient has been followed for 9 months without evidence of exposed bone or pus drainage (Figs. 2D-F).

\section{Discussion}

BPs are synthetic analogues of pyrophosphate, which is a natural compound that inhibits bone resorption (7). More potent BPs, especially ZA, are indicated at a dosage of $4 \mathrm{mg}$ monthly for controlling pain related to bone metastasis and multiple myeloma or an annual application of $5 \mathrm{mg}$ for the control of osteoporosis. It is noteworthy that BPs are extremely important in the prevention of 
bone fractures. The once-yearly injection of ZA is used as a substitute for weekly oral BP (alendronate) in the treatment of postmenopausal osteoporosis. Few studies have investigated the development of ONJ in patients receiving yearly $\mathrm{BP}$ for the treatment of osteoporosis $(3,8,9)$. Furthermore, to the best of our knowledge, this is the second
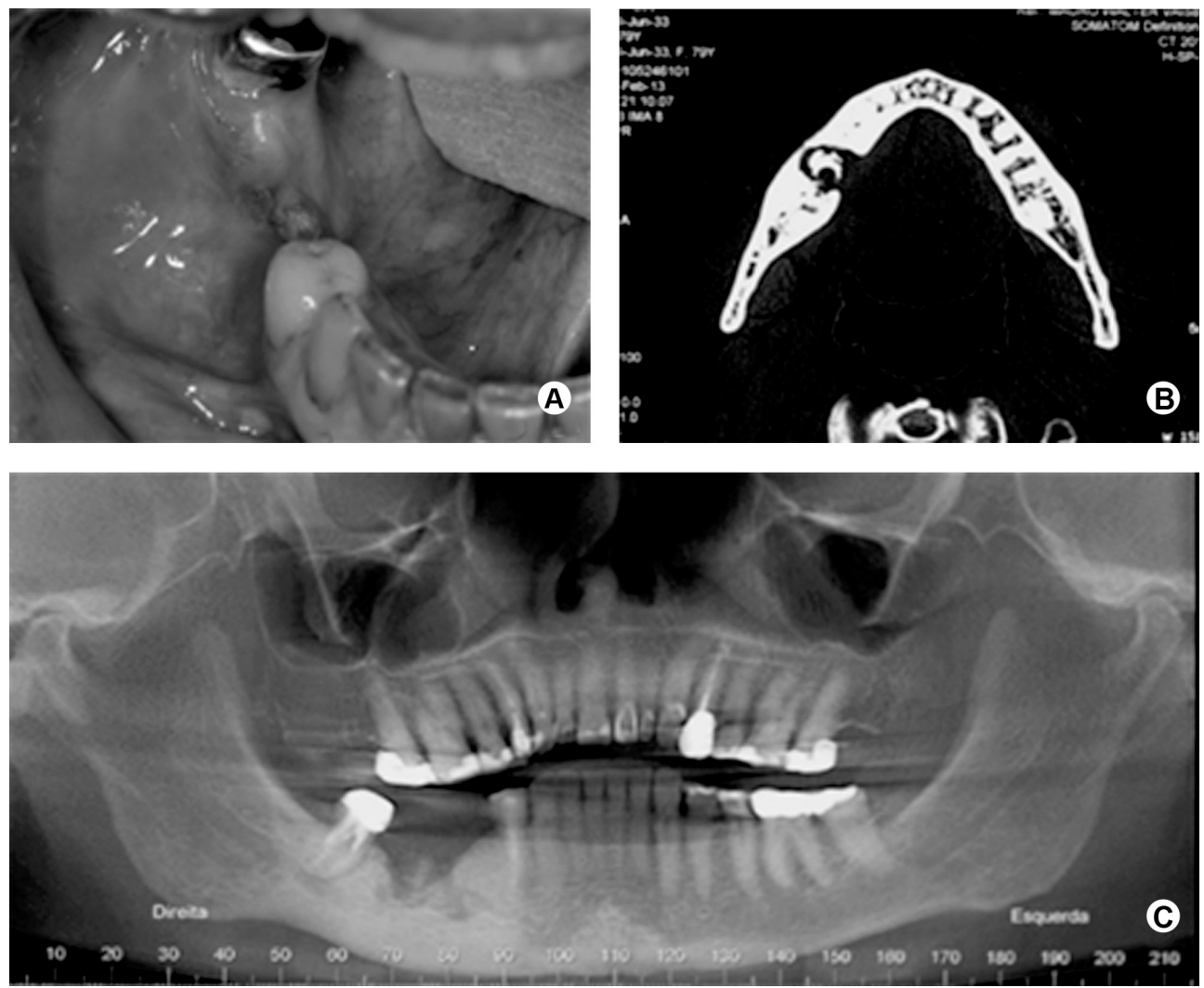

Figure 1. A: Exposed bone on the crest of the alveolar ridge. B: Computed tomography showing a destruction of the mandibular lingual cortical, and bone sequestration. In addition, it is possible to observe an increased radiopacity in the right side of the mandible. C: Reconstruction overview of cone beam computed tomography revealed an area of osseous trabeculae disorganization in the right side of the mandible.
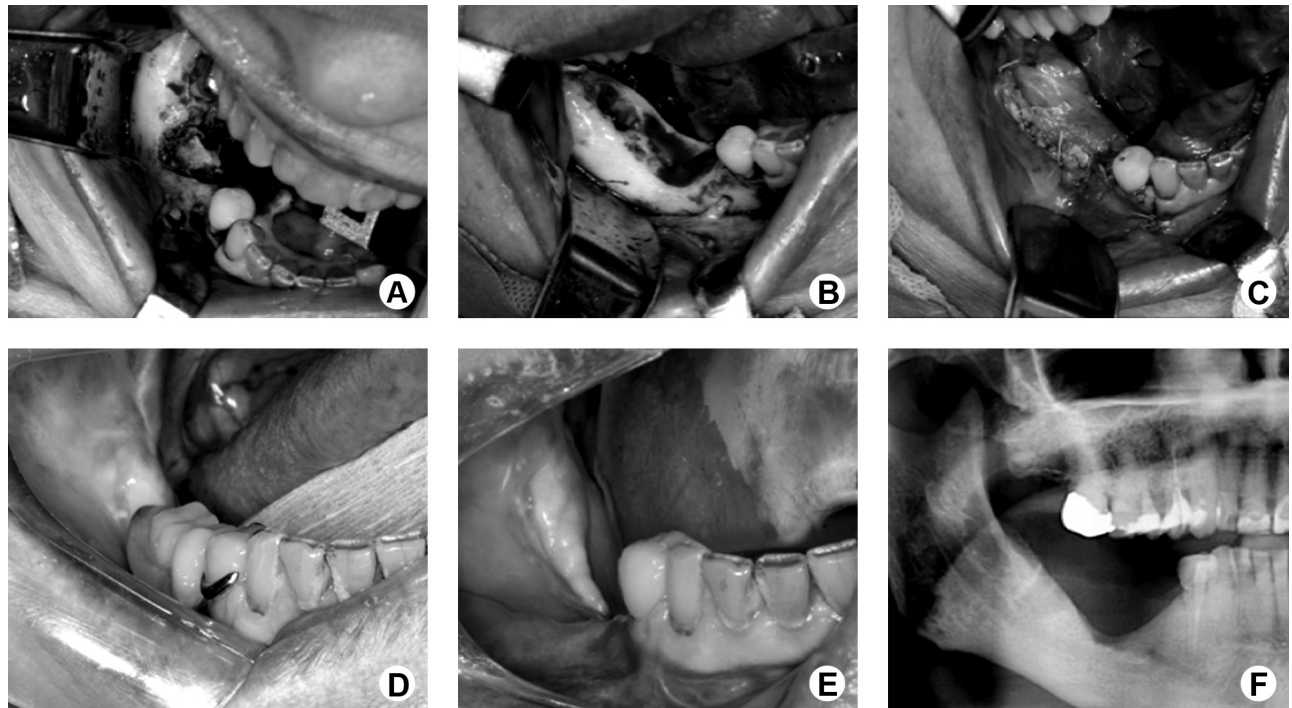

Figure 2. A: During the surgery, the bone necrosis is larger than the previous clinical image. B: All necrotic bone was removed until finding bleeding bone. C: The suture promoting primary closure of the wound. D: After one month of the surgery a lower removable partial denture was performed. E: Clinical features after 6 months of follow up. F: Panoramic radiography controls after 6 months of the surgery. 
case of ONJ developed after surgery for the placement of dental implants, and both cases affected the mandible in osteoporotic patients who were receiving once-yearly ZA. In Lee's study (9), the patient presented with ONJ after 2 infusions, and in our case, the patient had been treated with 5 applications.

The prevalence of ONJ in patients with malignant disease is considerably higher than in patients with benign diseases such as osteopathies, osteoporosis, Paget's disease, and hypercalcemia of any cause. Dentoalveolar surgeries have been reported to precede manifestation of ONJ in over $80 \%$ of cases. As a consequence, elective surgical procedures, such as dental implant insertion, are not indicated in patients with malignant disease and using $\mathrm{BP}$ therapy, whereas it remains uncertain whether implants can be placed in patients receiving oral or intravenous BP for the treatment of osteoporosis $(1,10,11)$. The incidence rate of ONJ related to yearly ZA remains to be determined. Moreover, ONJ in patients with osteoporosis who receive yearly zoledronic acid is possibly rarer and occurs later than that in monthly users (9). Magremanne and Reychler (10) stated that even with one infusion per year, the risk of ONJ is significant, although there are no data about the 'toxic' dose or duration of yearly ZA. Consequently, all patients receiving once-yearly infusions of BP for osteoporosis should be adequately informed concerning the risk of ONJ and oral examination is indicated before BP therapy to rule out local inflammation to minimize the risk of ONJ development (8).

The treatment of $\mathrm{ONJ}$ caused by $\mathrm{BP}$ remains challenging. Both conservative and surgical therapies have been proposed depending on the degree of clinical disease. The treatment is integrated and involves the use of antibiotics, local irrigation with antibiotic solution, local debridement and surgery. Radical treatment with segmental resection becomes necessary in cases of non-response to minor surgery or non-invasive procedures. Wilde et al. (12) described a technique for surgical treatment of ONJ that resembles the one used in our department. It is characterized by removing all of the necrotic bone and obtaining margins that are determined by the clinical appearance of bone bleeding; smoothing away all cut bone edges; and primary closure of the wound. However, it is important to consider the possibility of using non-invasive methods and the patient's general condition, and the risks and benefits of the surgery should be evaluated carefully.

Most studies have correlated ONJ with oncologic patients using BP. However, dentists and physicians must be alert to the possibility of ONJ occurrence even with once-yearly ZA therapy. In addition, osteoporotic patients who will start BP therapy should be submitted to a careful dental examination to improve their oral care.

\section{Resumo}

0 presente estudo teve como objetivo apresentar um caso de osteonecrose dos maxilares associada ao uso de ácido zoledrônico ( $5 \mathrm{mg}$ ) administrado uma vez ao ano para tratar a osteoporose. Uma mulher de 79 anos de idade estava em tratamento de osteoporose por 5 anos com 5 aplicações do ácido zoledrônico foi encaminhada para nossa avaliação. A paciente tinha sido submetida à colocação de implante dental e não houve osseointegração. Ao exame clínico, supuração e osso exposto no rebordo alveolar foram observados. Os exames radiográficos revelaram uma área osteolitica e sequestro ósseo. Ambos os aspectos clínicos e radiográficos eram sugestivos de osteonecrose. 0 tratamento consistiu de cirurgia para remover todo o osso afetado. A paciente está assintomática há 9 meses (desde a cirurgia). Cirurgiões-dentistas e cirurgiões orais devem estar atentos para a possibilidade de osteonecrose relacionada ao uso de injeções anuais de ácido zoledrônico para tratamento da osteoporose pós-menopausa.

\section{Acknowledgements}

Dr. Fabio Alves is a research fellow of Conselho Nacional de Pesquisa (CNPq).

\section{References}

1. Khosla S, Burr D, Cauley J, Dempster DW, Ebeling PR, Felsenberg D, et al.. American Society for Bone and Mineral Research. Bisphosphonateassociated osteonecrosis of the jaw: report of a task force of the American Society for Bone and Mineral Research. J Bone Miner 2007;22:1479-1491.

2. Cornish J, Bava U, Callon KE, Bai J, Naot D, Reid IR. Bone-bound bisphosphonate inhibits growth of adjacent non-bone cells. Bone 2011;49:710-716.

3. Räkel A, Boucher A, Ste-Marie LG. Role of zoledronic acid in the prevention and treatment of osteoporosis. Clin Interv Aging 2011;6:8999.

4. Tanvetyanon T, Stiff PJ. Management of the adverse effects associated with intravenous bisphosphonates. Ann Oncol 2006;17:897-907.

5. Grbic JT, Landesberg R, Lin SO, Mesenbrink P, Reid IR, Leung PC, et al.. Incidence of osteonecrosis of the jaw in women with postmenopausal osteoporosis in the health outcomes and reduced incidence with zoledronic acid once yearly pivotal fracture trial. JADA 2008;39:32-40.

6. Katz J, Ordoveza PA. Bisphosphonate-related osteonecrosis of the jaw (BRONJ) associated with a once-yearly IV infusion of zoledronic acid (Reclast) $5 \mathrm{mg}$ : two cases and review of the literature. Quintessence Int 2014;45:685-690

7. Goytia RN, Salama A, Khanuja HS. Bisphosphonates and osteonecrosis: potential treatment or serious complication? Orthop Clin North Am 2009;40:223-233.

8. Otto S, Sotlar K, Ehrenfeld M, Pautke C. Osteonecrosis of the jaw as a possible rare side effect of annual bisphosphonate administration for osteoporosis: A case report. J Med Case Rep 2011;5:477.

9. Lee JJ, Cheng SJ, Wang YP, Jeng JH, Chiang CP, Kok SH. Osteonecrosis of the jaws associated with the use of yearly zoledronic acid: Report of 2 cases. Head \& Neck 2013;35:6-10.

10 Magremanne $M$, Reychler $H$. Pentoxifylline and tocopherol in the treatment of yearly zoledronic acid-related osteonecrosis of the jaw in a corticosteroid-induced osteoporosis. J Oral Maxillofac Surg in press 2013.

11. Jacobsen $C_{1}$ Metzler P, Rössle M, Obwegeser J, Zemann W, Grätz K-W. Osteopathology induced by bisphosphonates and dental implants: clinical observations. Clin Oral Investig 2013;17:167-175.

12. Wilde $F$, Heufelder $M$, Winter $K$, Hendricks J, Frerich $B$, Schramm $A$, et al.. The role of surgical therapy in the management of intravenous bisphosphonates-related osteonecrosis of the jaw. Oral Surg Oral Med Oral Pathol Oral Radiol Endod 2011;111:153-163. 